\title{
Analysis of geometric accuracy of turned workpieces
}

Karol Vasilko, Zuzana Murčinková

Faculty of Manufacturing Technologies with a seat in Prešov, Technical University in Košice, Bayerova 1, 08001 Prešov, Slovak Republic, karol.vasilko@tuke.sk, zuzana.murcinkova@tuke.sk

Each construction of cutting machine tool activates geometric inaccuracies of the workpieces as a result of different stiffness of its joints. The acting of cutting force and the moving of its position leads to the deformation of the elastic joints of cutting machine tool and the elastic deformation of the workpiece appears. The aim is to maintain geometric modifications of the workpiece in required tolerances. The paper tries to identify these inaccuracies for case of a centre lathe.

Keywords: turning, tool, lathe, measurement, accuracy

\section{References}

[1] BUDA, J., BÉKÉS, J. (1967). Teoretické základy obrábania kovov, pp. 698. ALFA, Bratislava.

[2] DEMEČ, P., SVETLÍK, J., SEMJON, J. (2011). Virtuálne prototypovanie obrábacách strojov z hl'adiska dynamiky procesov obrábania, pp. 182. Technical University in Košice, Košice.

[3] DUGIN, A., POPOV, A. (2012). Effect of the processing materials on the ploughing force values. In: Manufacturing Technology, Vol. 12, No. 13, pp. 102-105. J. E. Purkyně University in Ústí nad Labem, Ústí nad Labem.

[4] GRZESIK, W. (2010). Podstawy skawania materialow metalowych. pp. 526. Wydawnictwa Naukowo-Techniczne, Warszawa.

[5] KUNDRÁK, J., GYÁNI, K., DESZPOTH, I. (2012). The effect of the borehole diameter on the machining times in hard machining. In: Manufacturing Technologies, Vol. 12, No. 13, pp. 144-150. J. E. Purkyně University in Ústí nad Labem, Ústí nad Labem.

[6] MÁDL, J., KVASNIČKA, J. (1998). Optimalizace obráběcího procesu, pp. 168. Czech Technical University in Prague, Prague.

[7] MURČINKO, J. (2012). The Application of MFG Templates in CAD/CAM Systems. In: Proceedings of 4th IEEE International Symposium on Logistics and Industrial Informatics LINDI 2012, pp. 17-20. Óbuda University, Budapest.

[8] MURČINKOVÁ, Z. (2011). Pružnost’ a pevnost’ 1 Mechanika poddajných telies, pp. 121. Technical University in Košice, Prešov.

[9] NOVÁK, P., MEŠKO, J., ŽMINDÁK, M. (2013). Finite Element Implementation of Multi-Pass Fillet Weld with Phase Changes. In: Manufacturing Technology, Vol. 13, No.1, pp.79-85. J. E. Purkyně University in Ústí nad Labem, Ústí nad Labem.

[10] PŘIKRYL, Z., MUSÍLKOVÁ, R. (1982). Teorie obrábění, pp. 235. SNTL, Prague.

[11] VASILKO, K., MÁDL, J. (2013). Teorie obrábění, pp. 526. J. E. Purkyně University in Ústí nad Labem, Ústí nad Labem.

[12] WEBER, H., LOLADZE, T. N. (1986). Grundlagen des Spanens. pp. 255. VEB Verlag Technik, Berlin. 